\title{
Spontaneous coffee senna poisoning in cattle: Report on 16 outbreaks ${ }^{1}$
}

\author{
Priscila M.S. Carmoㄹ, Luiz Francisco Irigoyen ${ }^{3}$, Ricardo B. Lucena², Rafael A. \\ Fighera $^{3}$, Glaucia D. Kommers ${ }^{3}$ and Claudio S.L. Barros ${ }^{3^{*}}$
}

ABSTRACT.- Carmo P.M.S., Irigoyen L.F., Lucena R.B., Fighera R.A., Kommers G.D. \& Barros C.S.L. 2011. Spontaneous coffee senna poisoning in cattle: Report on 16 outbreaks. Pesquisa Veterinária Brasileira 31(2):139-146. Departamento de Patologia, Universidade Federal de Santa Maria, 97105-900 Santa Maria, RS, Brazil. E-mail: claudioslbarros@uol.com.br

Sixteen outbreaks of Senna occidentalis (coffee senna) that occurred in cattle in the state of Rio Grande do Sul, Brazil, were reviewed. The great majority $(75 \%)$ of the outbreaks occurred in adult cattle at pasture during the autumn and winter months with $50 \%$ in May, evidencing a striking seasonality. Mortality rates varied from $4.2 \%$ to $55.2 \%$ and cattle died 2 days up to 2 weeks after showing clinical signs that included dry feces (occasionally diarrhea), muscle weakness, reluctance to move, tachypnea, instability of the hind limbs with dragging of the toes, tremors in muscles of the thighs, neck, and head, ear dropping, sternal recumbency, lateral recumbency and death. Myoglobinuria characterized by a dark red or black discolored urine was a consistent finding in cattle affected at pasture but not in those poisoned by ration contaminated with coffee senna beans. Creatine phosphokinase serum activity was marked ly elevated. Main gross changes observed in 23 necropsies involved skeletal muscles of the hind limbs. These changes consisted of varying degrees of paleness of muscle groups. Subepicardial and subendocardial hemorrhages were present in the hearts of all affected cattle. Histologically a segmental degenerative myopathy of striated muscles was present in every case and had a multifocal polyphasic or monophasic character. Myocardial (3/23), hepatic (3/ 13), renal (3/10), and splenic (1/6) microscopic lesions were observed occasionally. Myocardial lesions were mild and consisted of vacuolation of cardiomyocytes or focal fibrosis. Hepatic changes consisted of diffuse hepatocelular vacuolation, cytosegrosomes within hepatocytes, and individual hepatocellular necrosis. Kidneys had vacuolar degeneration of tubular epithelium associated with acidophilic casts (proteinosis) within tubular lumina. In the spleen there was marked necrosis of lymphocytes of the white pulp. No histological changes were found in the brains of 13 affected cattle. The data of this study suggest that coffee senna poisoning is an important cause of death in cattle in southern Brazil.

INDEX TERMS: Diseases of cattle, diseases of striated muscles, plant poisoning, coffee senna, Senna occidentalis, Fabaceae, Caesalpinioideae, poisonous plants.

RESUMO.- [Intoxicação espontânea por fedegoso em bovinos: relato de 16 surtos.] Dezesseis surtos de intoxicação por Senna occidentalis (fedegoso) em bovinos do

\footnotetext{
${ }^{1}$ Received on August 2, 2010.

Accepted for publication on September 15, 2010.

Part of the MS Dissertation of the first author.

2 Post-Graduate Program in Veterinary Medicine, major in Veterinary Pathology, Centro de Ciências Rurais, Universidade Federal de Santa Maria (UFSM), Santa Maria, RS 97105-900, Brazil.

${ }^{3}$ Departamento de Patologia, UFSM, Santa Maria, RS. * Corresponding author: claudioslbarros@uol.com.br
}

Rio Grande do Sul foram revisados. A grande maioria dos surtos $(75 \%)$ ocorreu em bovinos adultos em pastoreio durante o outono e inverno com $50 \%$ dos surtos em maio, evidenciando uma notável sazonalidade. Os coeficientes de mortalidade variaram de $4,2 \%$ a $55,2 \%$ e os bovinos morriam 2 dias a duas semanas após mostrarem sinais clínicos que incluíam fezes ressecadas (ocasionalmente diarreia), fraqueza muscular, relutância em mover-se, taquipneia, instabilidade dos membros pélvicos com arrastamento das pinças, tremores nos músculos das coxas, pescoço e cabeça; orelhas caídas, decúbito esternal, de- 
cúbito lateral, e morte. Mioglobinúria, caracterizada por urina vermelho-escura ou preta foi regularmente encontrada em bovinos afetados em pastoreio, mas não naqueles que se intoxicaram ao ingerir ração contaminada com as sementes da planta. A atividade sérica da creatina fosfocinase estava acentuadamente elevada. As principais alterações macroscópicas observadas em 23 necropsias envolviam os músculos esqueléticos dos membros pélvicos. Essas alterações consistiam de graus variáveis de palidez em grupos musculares. Hemorragias subepicárdicas e subendocárdicas ocorreram nos corações de todos os bovinos afetados. Histologicamente, miopatia degenerativa dos músculos estriados esteve presente em todos os casos e tinha um caráter multifocal monofásico ou polifásico. Lesões microscópicas no miocárdio (3/23), fígado (3/13), rim $(3 / 10)$ e baço (1/6) foram ocasionalmente observadas. As lesões miocárdicas eram discretas e consistiam de vacuolização dos cardiomiócitos ou fibrose focal. As lesões hepatocelulares consistiam de vacuolização difusa, formação de citossegrossomos e necrose individual. Nos rins havia degeneração vacuolar do epitélio tubular associada a cilindros eosinofílicos (proteinose) na luz tubular. No baço havia marcada necrose de linfócitos da polpa branca. Nenhuma alteração foi encontrada ao exame histológico do encéfalo de 13 bovinos afetados. Os dados deste estudo sugerem que a intoxicação por fedegoso é uma importante causa de morte em bovinos do sul do Brasil.

TERMOS DE INDEXAÇÃO: Doenças de bovinos, doenças dos músculos estriados, intoxicação por plantas, fedegoso, Senna occidentalis, Fabaceae, Caesalpinioideae, plantas tóxicas.

\section{INTRODUCTION}

Senna occidentalis (coffee senna), Fabaceae, Caesalpinioideae, formerly Cassia occidentalis, is an annual shrub $40-80 \mathrm{~cm}$ high, with elliptical pointed dark green leaves and bright golden yellow flowers (Barros 1993); seed pods are green with transverse brown bars when immature and brown when mature and dry (O'Hara et al. 1969). It sprouts in spring and blossoms in early summer. The pods are curved with extremities turned upwards (Fig.1) and seeds are triangular with about $0.5 \mathrm{~cm}$ in the major length. $S$. occidentalis is found in pastures, fertile soils, along road margins and as a contaminant weed of crops such as soybean, corn and sorghum (Schmitz \& Denton 1977, Colvin et al. 1986, Flory et al. 1992).

The ingestion of $S$. occidentalis is reported in several animal species inducing a disease characterized mainly by degenerative myopathy and cardiomyopathy. Spontaneous cases of the toxicosis have been reported in cattle from Texas (Henson et al. 1965, Pierce \& O'Hara 1967) and southern Brazil (Barros et al. 1990, Barth et al. 1994, Barros et al. 1999), pigs (Colvin et al. 1986, Martins et al. 1986) and horses (Brocq-Rousseau \& Bruere 1925) and the poisoning has been experimentally produced in cattle (Dollahite et al. 1964, Dollahite \& Henson 1965, Henson \& Dollahite 1966, Mercer et al. 1967, Read et al. 1968, O'Hara et al. 1969, O'Hara et al. 1970, Rogers et al. 1979, Barros et al. 1990),

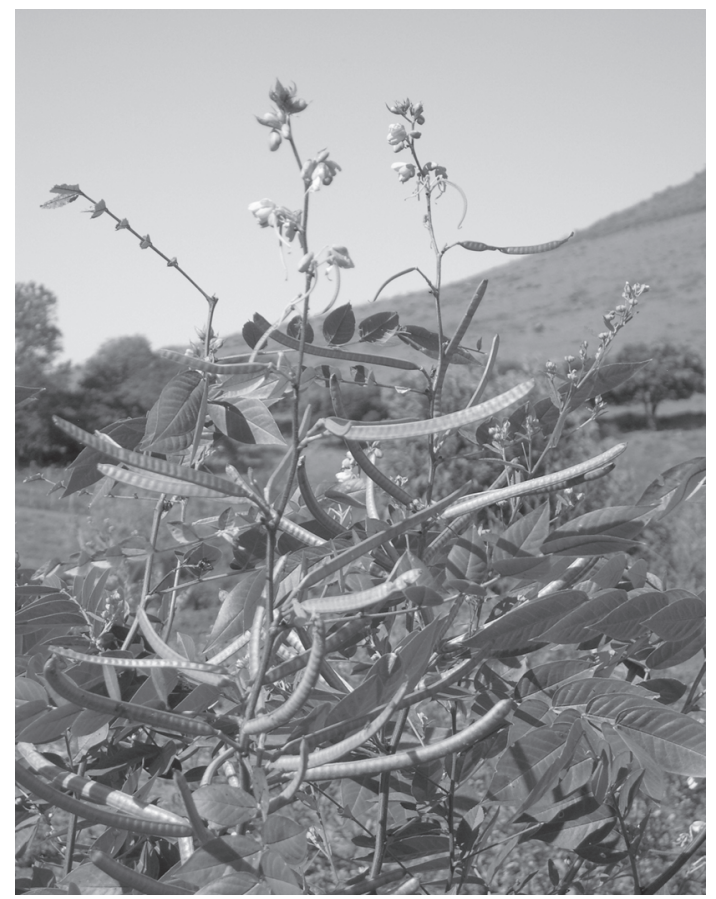

Fig.1. Blossoming specimen of Senna occidentalis. Typically the pods are curved with extremities turned upwards, leaves are dark pointed and green and flowers are bright golden yellow.

pigs (Colvin et al. 1986, Martins et al. 1986, Flory et al. 1992, Rodrigues et al. 1993), horses (Moussu 1925, Martin et al. 1981, Irigoyen et al. 1991), sheep and goats (Dollahite et al. 1964, Dollahite \& Henson 1965, Suliman et al. 1982, Barbosa-Ferreira et al. 2010), poultry (Simpson et al. 1971, Graziano et al. 1983, Hebert et al. 1983, Flory et al. 1992, Haraguchi et al. 1998, 2003, Hueza et al. 2007) and rabbits (Dollahite et al. 1964, Dollahite \& Henson 1965, O'Hara \& Pierce 1974a,b, Tasaka et al. 2000). Recurrent annual outbreaks of an acute multisystemic disease (hepatomyoencephalopathy syndrome) affecting young children in India have been attributed to the ingestion of $S$. occidentalis seeds (Vashishtha et al. 2007a,b, Panwar \& Kumar 2008). Seeds are the most toxic part of the plant (Henson \& Dollahite 1966, Martin et al. 1981), but pods, leaves and stems are also toxic (Mercer et al. 1967). The toxin in S. occidentallis responsible for the myodegeneration has not been definitely identified, although reported candidates include N-methylmorpholine (Kim et al. 1971), a toxic alkaloid (O'Hara et al. 1969), oxymethylanthraquinone (O'Hara et al. 1969) and a polar molecule, probably proteinaceous (Hebert et al. 1983). More recently dianthroene was identified as an anthraquinone-derived compound in S. occidentalis seeds (Haraguchi et al. 1996) and it was demonstrated that this compound can cause mitochondrial injury associated myopathy (Calore et al. 1997).

There are few reports of the spontaneous poisoning by $S$. occidentalis in cattle (Henson et al. 1965, Pierce and O'Hara 1967, Barros et al. 1990, Barth et al. 1994, Barros et al. 1999) and also there is evidence that the clinical disease that results from experimentally induced poisoning differs in some aspects 
from that observed in the naturally occurring disease (O'Hara et al. 1969). This paper reports the epidemiological, clinical and pathological data retrieved from the files of 16 spontaneous outbreaks of $S$. occidentalis poisoning in cattle diagnosed at our laboratory over the last 23 years.

\section{MATERIALS AND METHODS}

The necropsy files of the Laboratório de Patologia Veterinária (LPV) at the Universidade Federal de Santa Maria (UFSM), Santa Maria, southern Brazil, were reviewed looking for cases of Senna occidentalis poisoning in cattle. The period of time encompassed by this review was from 1987 (when the first outbreak of coffee senna poisoning was diagnosed in cattle at the LPV) until May 2010. Data retrieved from the files included epidemiological findings such as time of the year the outbreak occurred, type of feeding (eg, at pasture versus grain fed), and mortality, morbidity and lethality rates. Additionally, necropsy files were reviewed for clinical signs, clinical course of the disease, necropsy findings and histopathology. Recuts were made on stored paraffin blocks and histopathological findings were reviewed in every case.

Sixteen outbreaks of coffee senna poisoning in cattle were on file at LPV/UFSM and they were numbered for this study purposes in chronological order of occurrence from 1-16. The criteria for the diagnosis were the typical clinical signs (including clinical pathology in some cases) observed during on-site visits to the affected farms by one of the authors (CSLB), the evidence of the plant or its seeds being consumed by affected cattle, and typical gross and histopathological changes observed on the necropsied cattle. On each outbreak at least one necropsy was performed in the field; however four necropsies were performed in outbreak \# 1, two necropsies were performed both in outbreaks \# 3 and 6 , and 3 necropsies were performed in outbreak \# 5; that is, a total of 23 necropsies were performed in affected cattle of the 16 outbreaks. Histological examination included several organs (Table 1) and always included heart and different groups of skeletal muscles.

Table 1. Tissues sample for histopathological examination in each outbreak of Senna occidentalis poisoning in cattle

\begin{tabular}{|c|c|c|c|c|c|c|c|}
\hline \multirow[t]{2}{*}{ Outbreak \# } & \multicolumn{7}{|c|}{ Organs examined histologically } \\
\hline & $\begin{array}{l}\text { Skeletal } \\
\text { muscle }\end{array}$ & $\begin{array}{l}\text { Myocar- } \\
\text { dium }\end{array}$ & Spleen & $\begin{array}{l}\text { Lymph } \\
\text { nodes }\end{array}$ & Liver & Kidney & Brain \\
\hline $1(4)$ & 0 & - & 0 & 0 & 0 & 0 & 0 \\
\hline $2(1)$ & • & - & O & $\bigcirc$ & - & - & ○ \\
\hline $3(2)$ & - & $\bullet$ & ○ & O & O & O & ○ \\
\hline $4(1)$ & 0 & 0 & O & - & O & O & O \\
\hline $5(3)$ & - & ○ & $\bigcirc$ & 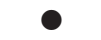 & $\bullet$ & O & ○ \\
\hline $6(2)$ & - & - & 0 & 0 & • & • & 0 \\
\hline 7 (1) & - & - & • & 0 & 0 & ○ & 0 \\
\hline $8(1)$ & - & • & ○ & ○ & ○ & O & $\bullet$ \\
\hline $9(1)$ & - & ○ & O & O & - & - & • \\
\hline 10 (1) & - & 0 & 0 & 0 & 0 & 0 & - \\
\hline $11(1)$ & ○ & ○ & O & O & O & O & • \\
\hline 12 (1) & 0 & - & 0 & 0 & 0 & 0 & 0 \\
\hline $13(1)$ & 0 & 0 & 0 & 0 & $\bullet$ & 0 & ○ \\
\hline 14 (1) & • & 0 & 0 & 0 & 0 & 0 & 0 \\
\hline 15 (1) & • & 0 & $\bigcirc$ & 0 & 0 & 0 & 0 \\
\hline $16(1)$ & - & - & 0 & 0 & 0 & O & 0 \\
\hline
\end{tabular}

- = Examined; $O=$ not examined. The number within parentheses indicates the number of affected cattle necropsied in that outbreak.

\section{RESULTS}

Twelve out of the 16 outbreaks (75\%) of Senna occidentalis poisoning occurred in cattle at pasture (Table 2 ) in fields that were used in the previous year for soybean, and, less commonly, corn and rice crops. S. occidentalis is a common invader of such fields after the soy bean is harvested. All outbreaks occurred from mid-Autumn to mid-Winter (April-July) and half of them (8/16) occurred in May, usually after the first frost or after the first cool days. Cattle involved in the outbreaks were mostly adults but calves under 1-year old (1/16) and yearling calves $(2 / 16)$ were occasionally affected. Mortality rates varied from $4.2 \%$ to $55.2 \%$. Morbidity and lethality rates were impossible to calculate precisely since mildly affected cattle which recovered could be difficult to detect. However, in general, recovery was uncommon and once a bovine was recumbent it eventually died after a clinical course that lasted from 2 days up to 2 weeks.

Clinical signs were similar in cattle from all outbreaks and included dry feces, muscle weakness, reluctance to move, tachypnea, instability (swaying) of the hind limbs with dragging of the toes, tremors in muscles of the thighs, neck, and head, ear dropping, sternal recumbency, lateral recumbency, and death. In outbreak \#1, diarrhea was the initial clinical sign. In outbreaks \# 1 and 11 some cattle became sick and died even 1-2 weeks after they had been removed from the source of the poisonous plant. After assuming lateral recumbency, cattle remained alert and would drink and eat if water and food were made available.

Myoglobinuria characterized by a dark red or black discolored urine (Fig.2) was a consistent finding in cattle affected at pasture but not in those poisoned by ration contaminated with coffee senna beans. In outbreak \# 1 serum samples of 3 cattle were tested for creatine phosphokinase (CK) activity which were 1,213ui/dl; 54,047ui/dl; and 14,787 $\mathrm{ui} / \mathrm{dl}$ (normal $=65 \mathrm{ui} / \mathrm{dl})$ and aspartate transaminase was determined in the serum of one calf as 170ui/dl (normal 60150ui/dl). In outbreak \# 10 serum CK activity measured in a cow on the day of its death was 30,427 ui/dl.

Main gross changes involved skeletal muscles of the hind limbs. These changes consisted of varying degrees of paleness which resulted in a subtle or marked discoloration involving a portion of a muscle, a whole muscle or several muscles. Some involved muscles appeared slightly paler than normal (Fig.3), while other affected muscles in the same or in other animal had a pronounced fish flesh aspect (Fig.4). Grossly the most affected muscles were the quadriceps femoris, semitendinosum, semimebranosum, adductor, sartorius and pectineus. Subepicardial and subendocardial hemorrhages were present in the hearts of all affected cattle and pale areas of discoloration were observed in myocardium of one case. Kidneys had a normal color even in those several cases in which dark red or black urine was observed.

Histologically a segmental degenerative myopathy of striated muscles were present in every case, the acute phase of which consisted of swollen hyalinzed fibers evolving to foccular hyaline contractile muscle elements enclosed by the sarcolemma sheaths (Fig.5). Affected fibers were intercalated 


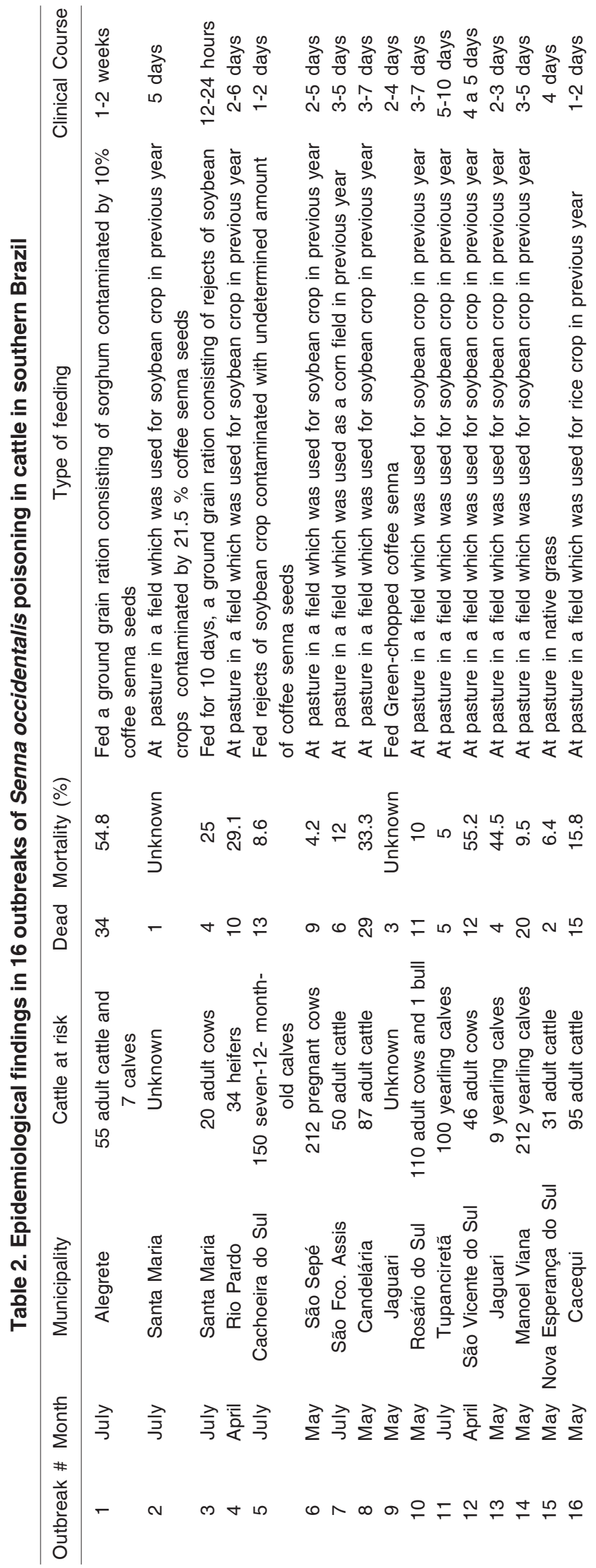

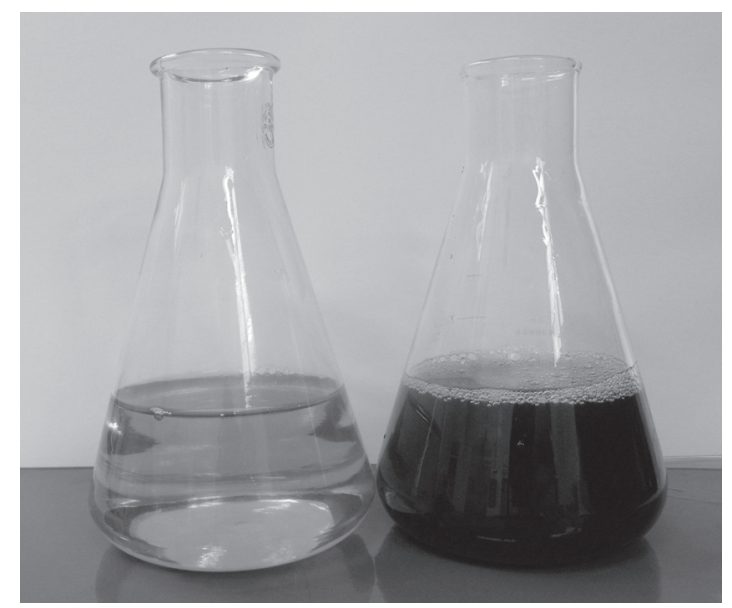

Fig.2. Myoglobinuria characterized by black discolored urine from a bovine affected by Senna occidentalis (right) compared with urine from a normal bovine (left).

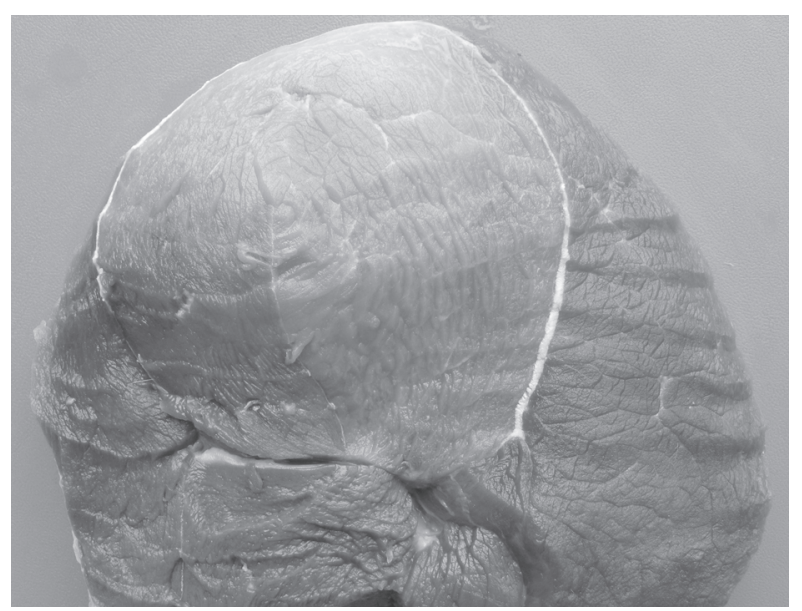

Fig.3. Hind limb striated muscle (M. quadriceps femoris) from a bovine affected by Senna occidentalis poisoning. At left there a slightly, almost imperceptible, discolored white area.

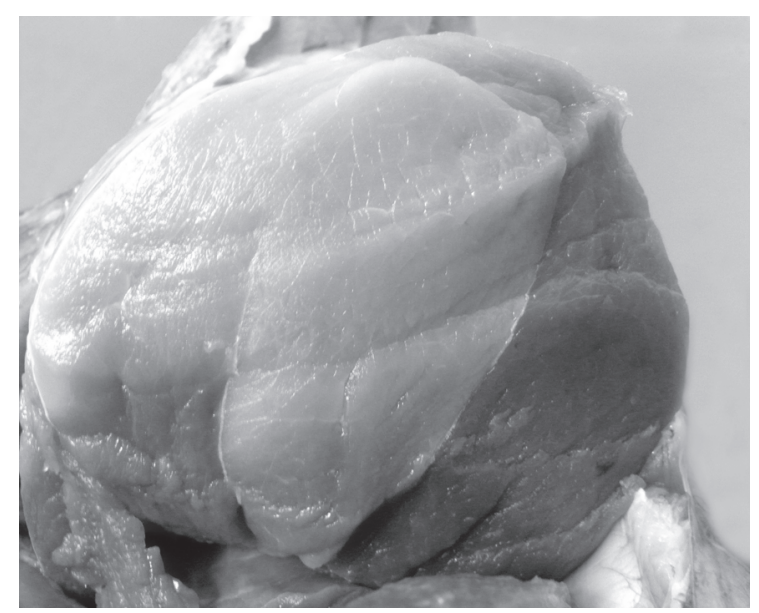

Fig.4. Hind limb striated muscle (M. quadriceps femoris) from a bovine affected by Senna occidentalis poisoning. At left there is a marked large area of white discoloration which imparts a fish flesh aspect to the affected muscle. 


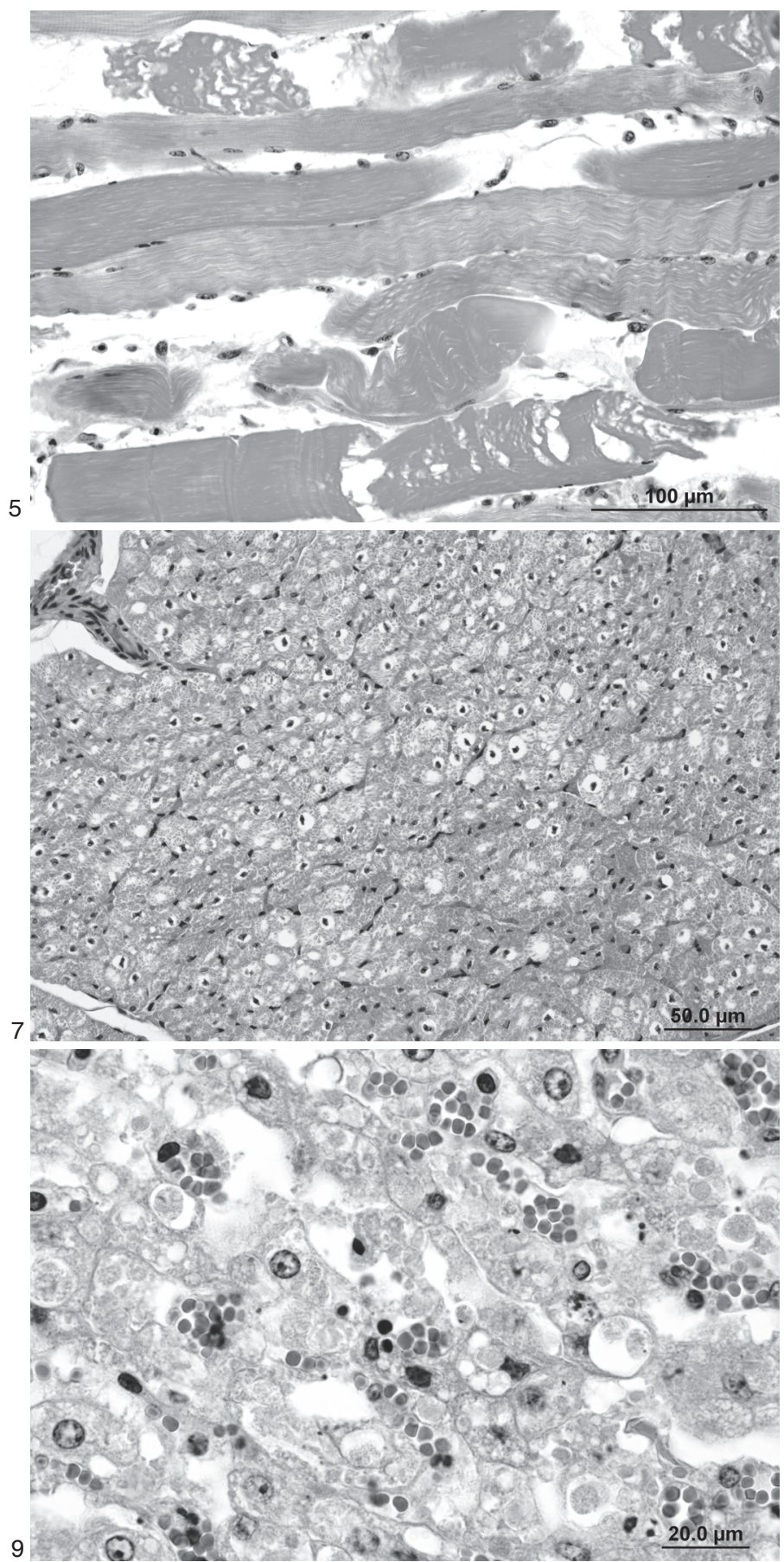

Fig.5. Acute segmental degenerative myopathy of striated muscle from a bovine affected by Senna occidentalis poisoning. Some fibers are swollen and hyalinized and others consist of floccular hyaline contractile muscle elements enclosed by preserved sarcolemma sheaths. HE, obj.20x.

Fig.7. Vacuolation of cardiomyocytes in the myocardium from a bovine affected by Senna occidentalis poisoning. HE, obj.20x.

Fig.9. Liver from a bovine affected by Senna occidentalis. There are diffuse vacuolation of hepatocytes, individual hepatocellular necrosis and eosinophilic hyaline proteinaceous inclusions (cytosegrosomes) within hepatic cells. HE, obj. $40 x$.
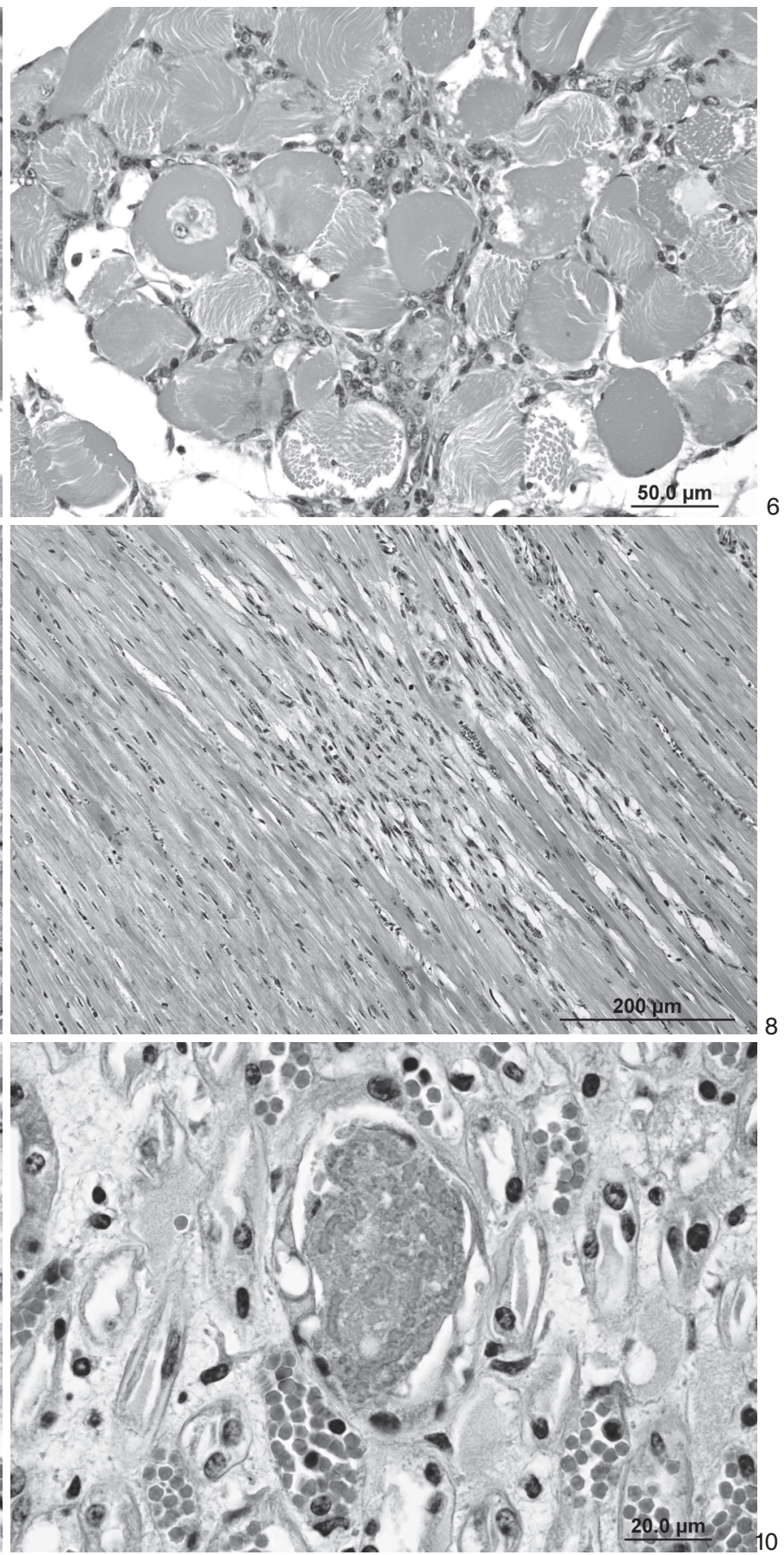

Fig.6. Regenerative changes with invasion of the affected fibers by macrophages and proliferation of satellite cells are seen in a transverse section of a striated muscle from a bovine affected by Senna occidentalis poisoning. HE, obj.40x.

Fig.8. Focal fibrosis in the myocardium from a bovine affected by Senna occidentalis poisoning. HE, obj.20x.

Fig.10. Kidney from a bovine affected by Senna occidentalis. There is vacuolar degeneration of tubular epithelium and acidophilic casts (proteinosis) within the tubular lumen. HE, obj.40x. 
with normal ones. In more advanced lesions, regenerative changes took place with invasion of the affected fibers by macrophages and proliferation of satellite cells (Fig.6). Striated muscle lesions had a multifocal distribution and could be monophasic (4/23) or polyphasic (19/23). Although muscles of the hind limbs were consistently affected, lesions were also observed in several other muscle groups, as of the shoulder, diaphragm, intercostals and mastigatories.

Histological myocardial lesions were found in fewer cases (3/23) and were mild or focal. In two cases there were vacuolation of cardiomyocytes (Fig.7) and in another one multifocal fibrosis of the myocardium was observed (Fig.8). In several hearts of affected cattle individual cardiomyocytes or clusters of this cell have an acidophilic cytoplasm and a picnotic nuclei. However these changes were considered artifacts or non-related lesions since identical findings were observed in the myocardium of most of the cattle that die from different causes and are necropsied at our laboratory.

Hepatic histological changes were observed in three out of eight cases in which this organ was examined; lesions consisted of diffusely vacuolated hepatocytes, individual hepatocellular necrosis; additionally within the cytoplasm of hepatic cells there were eosinophilic hyaline proteinaceous inclusions (cytosegrosomes) (Fig.9). In the $10 \mathrm{ca}-$ ses in which the kidney was histologically examined, lesions were found in three and consisted of vacuolar degeneration of epithelial cells lining renal tubules associated with acidophilic casts (proteinosis) within tubular lumina (Fig.10). The spleen was histologically examined in six cases and in one there was marked necrosis of lymphocytes of the white pulp (Fig.11). No histological changes were found in the brain of 13 affected cattle.

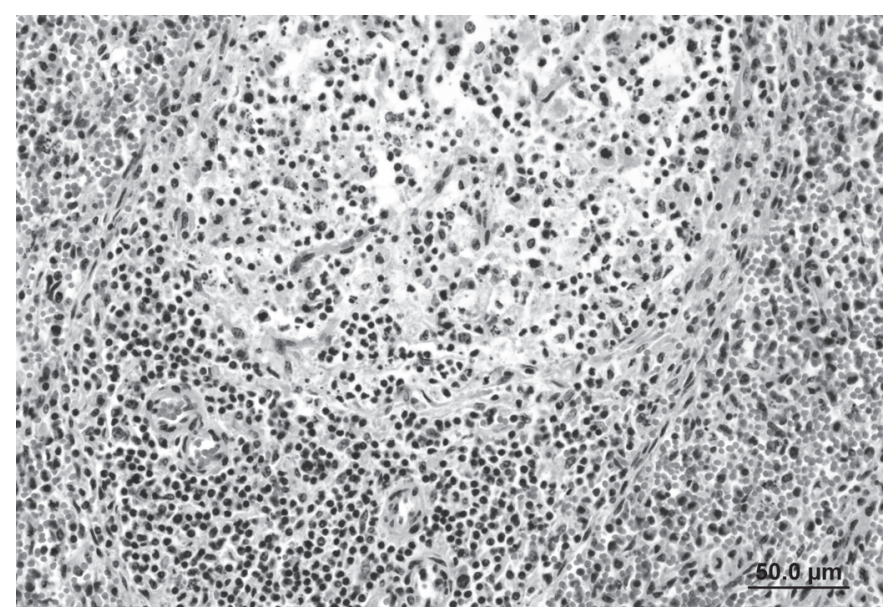

Fig.11. Necrosis of follicular lymphocytes is observed in the spleen from a bovine affected by Senna occidentalis. There is necrosis of follicular lymphocytes. HE, obj.20x.

\section{DISCUSSION}

The results of this study indicate that Senna occidentalis poisoning is an important cause of death in cattle in southern Brazil and that mortality rates can be as high as $55 \%$. Some epidemiological data derived from the study of these 16 outbreaks should be helpful in the field diagnosis of this condition. The disease has a definite seasonality extending from April to July (Autumn and Winter) with most cases occurring in May. The same seasonality has been described from the USA where cases of the toxicosis are seen in cattle usually after a frost (Henson et al. 1965, Pierce \& O'Hara 1967). Coffee senna poisoning was, by and large, most common in cattle at pasture. Less frequently the intoxication was associated with contaminated grain ration fed to cattle; in one instance sorghum grain was contaminated by the beans of coffee senna and in another two instances the toxic beans were present in the rejects of soybean crops. In one occasion the owner chopped green stands of S. occidentalis and fed them to cattle; this form of poisoning in cattle has been previously reported in relation to $S$. obtusifolia toxicosis (Nicholson et al. 1977, McCormack \& Neisler 1980).

Another point of interest is that the disease occurs mainly in adult cattle, a fact which helps to differentiate this toxicosis from nutritional myopathty caused by of vitamin $\mathrm{E}$ and selenium deficiency and which affects mainly young stock (Barros et al. 1988).

The main gross lesions of coffee senna poisoning in cattle are paleness of skeletal muscle, particularly of the hind limb, although histologically it can be demonstrated that the skeletal muscle degeneration is widespread affecting various muscles groups in the body. Although the muscle lesion in coffee senna poisoning is described as a typically monophasic multifocal myopathy (Van Vleet \& Valentine 2007), in most cases of this study the lesions were a polyphasic multifocal myopathy. Pathologic classification of muscle necrosis can be described as monophasic and polyphasic; monophasic lesions are of the same duration, indicative of a single insult. Polyphasic lesions indicate an ongoing degenerative process (Valentine \& McGavin 2007). A multifocal monophasic lesion could represent a toxin being fed on one occasion; however in cases were repeated ingestion of coffee senna occurred, new lesions (segmental necrosis) would form at the same time that regeneration is taking place resulting in a multifocal and polyphasic disease, which was the case in the majority of cases in this study.

In S. occidentalis toxicosis pale streaks may occur in cardiac muscle of some cattle, especially in the left ventricle, beneath the serosal surface (Schmitz \& Denton 1977). However it is recognized that degeneration is less severe and less extensive in cardiac muscle than in skeletal muscle (Pierce \& O'Hara 1967) and actually cardiac lesions are not mentioned in several reports of spontaneous $S$. occidentalis poisoning in cattle (Henson et al 1965, Henson \& Dollahite 1966, Barth et al. 1994, O'Hara et al. 1969, Barros et al. 1999). Cardiac lesions were found in three cattle of this report. In two occasions the lesions consisted of vacuolation of the fiber sarcoplasm in a way very similar to what is described in one report that studied the cardiac lesions of cattle experimentally poisoned by S. occidentalis (Read et al. 1968). However, the lesions observed in our cases were mild. Thus, the hepatic lesions observed in S. occidentalis poisoning in cattle should not be considered as secondary to congestive heart failure. 
Our data indicate that cardiac lesions are not an import feature of coffee senna poisoning in cattle and that they cannot be held responsible for the hepatic lesions. This idea is backed up by other reports which do not attribute heart failure in coffee senna poisoning in cattle to myocardial degeneration; in one of these reports (O'Hara et al. 1969) the changes in electrocardiograms (ECG) were observed only terminally in cattle with marked increase of serum $\mathrm{K}^{+}$concentration, and it was concluded that the changes in ECG were largely the result of hyperkalemia, rather than the effect of some plant toxin on the myocardium. Further, the type and the distribution of hepatocellular degeneration found in our cases are compatible with a direct hepatotoxic effect of some toxic principle in the plant. The reason that only three out of 13 examined livers had degenerative lesions could be due to a dose-dependent effect. There is evidence that a high rate of ingestion is important in development of the hepatic lesions. Such rates are probably seldom attained under natural circumstances (Rowe et al. 1987). Interestingly is the fact that lesions found in the livers of cattle from this study are similar to those described in children accidentally intoxicated by coffee senna beans (Vashishtha et al. 2007a,b, Panwar \& Kumar 2008).

Dark red or black urine is a common finding in cattle poisoned by S. occidentalis at pasture (Henson et al. 1965, Pierce \& O'Hara 1967, Schmitz \& Denton 1977) and this assertion is corroborated by our findings. This change is explained by the extensive muscle damage with subsequent release of myoglobin into the circulatory system; since the renal threshold to myoglobin is low, it would spill out in the urine (Mercer et al. 1967). Renal lesions observed in cases of senna toxicosis could be attributed to myoglobinuria. Although neither hemoglobin nor myoglobin is a primary nephrotoxin, they may contribute, by other mechanisms, such as hypotension, to renal lesions (Maxie \& Newman 2007). In one report (Mercer et al. 1967) it was demonstrated that both myoglobin and hemoglobin are responsible for the urine discoloration in senna toxicosis and that hemoglobin would arise from kidney hemorrhages.

Splenic lesions, characterized by follicular lymphocyte necrosis were observed in one out of six cases of this report. It is not possible to conclude that this is related to the effects of the plant but it is worth to note that in one report of coffee senna poisoning in cattle the spleen had a "small amount" of perifollicular necrosis and mild infiltration of polymorphonuclear leukocytes (Henson \& Dollahite 1966).

Senna bean toxicosis in children (Vashishtha et al. 2007a,b, Panwar \& Kumar 2008) is associated with brain lesions such as mild spongiosis with focal gliosis (Vashishtha et al. 2007a). No lesions were found in the brain of 10 affected cattle examined in this study.

Aknowledgements.- The authors thanks Dr. Raquel R. Rech for technical assistance with the photomicrographs.

\section{REFERENCES}

Barbosa-Ferreira M., Pfister J.A., Gotardo A.T., Maiorka P.C. \& Górniak S.L. 2010. Intoxication by Senna occidentalis seeds in pregnant goats: Prenatal and postnatal evaluation. Exp. Toxicol. Pathol. (In publication)
Barros C.S.L. 1993. Intoxicações por plantas que afetam o sistema muscular, p.201-203. In: Riet-Correa F., Méndez M.C. \& Schild A.L (Eds), Intoxicações por Plantas e Micotoxicoses em Animais Domésticos. Hemisfério Sul do Brasil, Pelotas.

Barros C.S.L., Barros S.S., Santos M.N. \& Metzdorf L.L. 1988. Miopatia nutricional em bovinos no Rio Grande do Sul. Pesq. Vet. Bras. 8:51-55.

Barros C.S.L., Pilati C., Andujar M.B., Graça D.L., Irigoyen L.F., Lopes S.T. \& Santos C.F. 1990. Intoxicação por Cassia occidentalis (Leg. Caes.) em bovinos. Pesq. Vet. Bras. 10:47-58.

Barros C.S.L., Ilha M.R.S., Bezerra Jr P.S., Langhor I.M. \& Kommers G.D. 1999. Intoxicação por Senna occidentalis (Leg. Caesalpinoideae) em bovinos em pastoreio. Pesq. Vet. Bras. 19:68-70.

Barth A.T., Kommers G.D., Salles M.S., Wouters F. \& Barros C.S.L. 1994. Coffee senna (Senna occidentalis) poisoning in cattle. Vet. Human Toxicol. 36:541-545.

Brocq-Rousseau \& Bruere P. 1925. Accidents mortels sur des cheveaux a la graine de Cassia occidentalis L. Compt. Rend. Soc. Biol. 92:555557.

Calore E.F., Cavalieri M.J., Haraguchi M., Górniak S.L., Dagli M.L.Z., Raspatini P.C.F. \& Calore N.M.P. 1997. Experimental mitochondrial myopathy induced by chronic intoxication by Senna occidentalis seeds. J. Neurol. Sci. 146:1-6.

Colvin B.M., Harrison L.R., Sangster L.T. \& Gosser H.S. 1986. Cassia occidentalis toxicosis in growing pigs. J. Am. Vet. Med. Assoc. 189:423-426.

Dollahite J.W. \& Henson I.B. 1965. Toxic plants as the etiologic agent of myopathies in animals. Am. J. Vet. Res. 26:749-752.

Dollahite J.W., Henson I.B. \& Householder G.T. 1964. Coffee senna (Cassia occidentalis) poisoning in animals. Tex. Agric. Exp. Stn Progr. Rep. 2318, Texas A \& M University. 2p.

Flory W., Spainhour C.B., Colvin B. \& Herbert C.D. 1992. The toxicologic investigation of a feed grain contaminated with seeds of the plant species Cassia. J. Vet. Diagn. Invest. 4:65-69.

Graziano M.J., Flory W., Seger C.L. \& Hebert C.D. 1983. Effects of a Cassia occidentalis extract in the domestic chicken (Gallus domesticus). Am. J. Vet. Res. 44:1238-1244.

Haraghuchi M., Górniak S.L., Dagli M.L.Z, Formignone F. \& Raspatini P.C. 1996. Determinação dos constituintes químicos das frações tóxicas de fedegoso (Senna occidentalis L.) 19ํㅡㄹ Encontro Anual da Sociedade Brasileira de Química, Poços de Caldas, MG, p.96. (Resumo)

Haraguchi M., Calore E.E., Dagli M.L.Z., Cavaliere M.J., Calore N.M.P. Weg, R., Raspantini P.C. \& Górniak S.L. 1998. Muscle atrophy induced in broiler chicks by parts of Senna occidentalis seeds. Vet. Res. Commun. 22:265-271.

Harahuchi M., Dagli M.L.Z., Raspatini P.C. \& Górniak S.L. 2003. The effects of low doses of Senna occidentalis seeds on broiler chickens. Vet. Res. Commun. 27:231-238.

Hebert C.D., Flory W., Seger C. \& Blanchard R.E. 1983. Preliminary isolation of a myodegenerative toxic principle from Cassia occidentalis. Am. J. Vet. Res. 44:1370-1374.

Henson I.B. \& Dollahite J.W. 1966. Toxic myodegeneration in calves produced by experimental Cassia occidentalis intoxication. Am. J. Vet. Res. 27:947-949.

Henson I.B., Dollahite J.W., Bridges C.H. \& Rao R.R. 1965. Myodegeneration in cattle grazing Cassia species. J. Am. Vet. Med. Assoc. 147:142-145.

Hueza I.M., Latorre A.O., Raspantini P.C.F., Raspantini L.E.R., MarianoSouza D.P., Guerra J.L. \& Górniak S.L. 2007. Effect of S. occidentalis in broiler chickens. J. Vet. Med. A, Physiol. Pathol. Clin. Med. 54:179-185.

Irigoyen L.F., Graça D.L. \& Barros C.S.L. 1991. Intoxicação experimental por Cassia occidentalis (Leg. Caes.) em eqüinos. Pesq. Vet. Bras. 11:35-44. 
Kim H.L., Camp B.J. \& Grigsby R.D. 1971. Isolation of a methylmorpholine from the seeds of Cassia occidentalis L. (Coffee Senna). J. Agric. Food Chem. 19:198-199.

Martin B.W., Terry M.K., Bridges C.H. \& Bailey Jr E.M. 1981. Toxicity of Cassia occidentalis in the horse. Vet. Hum. Toxicol. 23:416-417.

Martins E., Martins V.M.V., Riet-Correa F., Soncini R.A. \& Paraboni S.V. 1986. Intoxicação por Cassia occidentalis (Leguminosae) em suínos. Pesq. Vet. Bras. 6:35-38.

Maxie M.G. \& Newman S.J. 2007. Urinary system, pigmentary changes, p.475. In: Maxie M.G. (Ed.), Jubb, Kennedy, and Palmer's Pathology of Domestic Animals. Vol.2. $5^{\text {th }}$ ed. Saunders Elsevier, Philadelphia.

McCormack J.E. \& Neisler W.E. 1980. Cassia obtusifolia (sicklepod) toxicity in a dairy herd. Vet. Med., Small Anim. Clin. 75:1849-1851.

Mercer H.D., Neal F.C., Himes J.A. \& Edds G.T. 1967. Cassia occidentalis toxicosis in cattle. J. Am. Vet. Med. Assoc. 151:735-741.

Moussu R. 1925. L'íntoxication par le graines de Cassia occidentalis L. est due a une toxalbumine. Compt. Rend. Soc. Biol. 92:862-863.

Nicholson S.S., Thorton J.T. \& Rimes Jr A.J. 1977. Toxic myopathy in dairy cattle caused by Cassia obtusifolia in greenchop. Bovine Pract. 12:120.

O'Hara P.J. \& Pierce K.R. 1974a. A toxic myopathy caused by Cassia occidentalis. I. Morphologic studies in poisoned rabbits. Vet. Pathol. 11:97-109.

O'Hara P.J. \& Pierce K.R. 1974b. A toxic cardiomyopathy caused by Cassia occidentalis. II. Biochemical studies in poisoned rabbits. Vet. Pathol. 11:110-124.

O'Hara P.J., Pierce K.R. \& Read W.K. 1969. Degenerative myopathy associated with the ingestion of Cassia occidentalis L.: Clinical and pathological features of the experimentally induced disease. Am. J. Vet. Res. 30:2173-2180.

O'Hara P.J., Pierce K.R., Read W.K. 1970. Effects of vitamin E and se1enium on Cassia occidentalis intoxication in cattle. Am. J. Vet. Res. 31:2151-2156.

Panwar R.S. \& Kumar N. 2008. Cassia occidentalis toxicity causes recurrent outbreaks of brain disease in children in Saharanpur. Indian J. Med. Res. 127:413-414.
Pierce K.R. \& O'Hara P.J. 1967. Toxic myopathy in Texas cattle. Southwestern Vet. 20:179-183.

Read W.K., Pierce K.R. \& O'Hara P.J. 1968. Ultrastructural lesions of an acute toxic cardiomyopathy of cattle. Lab. Invest. 18:227-231.

Rodrigues U., Riet-Correa F. \& Mores N. 1993. Intoxicação experimental em suínos com baixas concentrações de Senna occidentalis. Pesq. Vet. Bras. 13:57-66.

Rogers R.J., Gibson J. \& Reichman K.O. 1979. The toxicity of Cassia occidentalis for cattle. Aust. Vet. J. 55:408-412.

Rowe L.D., Corrier D.E., Reagor J.C. \& Jones L.P. 1987. Experimentally induced Cassia roemeriana poisoning in cattle and goats. Am. J. Vet. Res. 48:992-997.

Schmitz D.G. \& Denton J.H. 1977. Senna bean toxicity in cattle. Southwestern Vet. 30:165-170

Simpson C.F., Damron B.L. \& Harms R.H. 1971. Toxic myopathy of chicks fed Cassia occidentalis seeds. Avian Dis. 15:284-290.

Suliman H.B., Wasfi I.A. \& Adam S.E.I. 1982. The toxicity of Cassia occidentalis to goats. Vet. Hum. Toxicol. 24:326-330.

Tasaka A.C., Weg R., Calore E.E., Sinhorini I.L., Dagli M.L.Z., Haraguchi M. \& Górniak S.L. 2000. Toxicity testing of Senna occidentalis seed in rabbits. Vet. Res. Commun. 24:573-582.

Valentine B.A. \& McGavin M.D. 2007. Skeletal muscle, necrosis and regeneration p.985-989. In: McGavin M.D. \& Zachary J.F. (Eds), Pathologic Basis of Veterinary Disease. $4^{\text {th }}$ ed. Mosby Elsevier, St Louis.

Van Vleet J.F. \& Valentine B.A. 2007. Cassia spp. toxicity, p.245-247. In. Maxie M.G. (Ed.), Jubb, Kennedy, and Palmer's Pathology of Domestic Animals. Vol.3. $5^{\text {th }}$ ed. Saunders Elsevier, Philadelphia.

Vashishtha V.M., Nayak N.C., John T.J. \& Amod K. 2007a. Recurrent annual outbreaks of a hepato-myo-encephalopathy syndrome in children in western Uttar Pradesh, India. Indian J. Med. Res. 125:523533.

Vashishtha V.M., Amod K., John T.J. \& Nayak N.C. 2007b. Cassia occidentalis poisoning as the probable cause of hepatomyoencephalopathy in children in western Uttar Pradesh. Indian J. Med. Res. 125:756-762. 